\title{
Leptopezella, a new Southern Hemisphere genus of Ocydromiinae (Diptera: Empidoidea: Hybotidae)
}

\author{
BRADLEY J. SINCLAIR ${ }^{1} \&$ JEFFREY M. CUMMING ${ }^{2}$ \\ ${ }^{1}$ Entomology, Ontario Plant Laboratories, Canadian Food Inspection Agency, K.W. Neatby Bldg., C.E.F., 960 Carling Ave., Ottawa, \\ ON, Canada K1A 0C6. E-mail: sinclairb@inspection.gc.ca \\ ${ }^{2}$ Invertebrate Biodiversity, Agriculture and Agri-Food Canada, K.W. Neatby Bldg., C.E.F., 960 Carling Ave., Ottawa, ON, Canada \\ K1A 0C6. E-mail: cummingjm@agr.gc.ca
}

\begin{abstract}
Leptopezella, gen. nov. is described to include one new species from Bolivia (L. masneri) and three new species from Australia (L. anatolica, L. perata, L. spinosa).
\end{abstract}

Key words: Leptopezella, Hybotidae, Diptera, Bolivia, Australia, taxonomy

\section{Introduction}

The genera of Ocydromiinae (sensu Sinclair \& Cumming 2006) of the Southern Hemisphere were keyed by Sinclair \& Cumming (2000). In their key, two genera remained unnamed and undescribed. "Undescribed genus B" was subsequently named Chvalaea and described by Papp \& Földvári (2001). In the present study "undescribed genus A", characterized by the absence of cell dm and presence of stout ventral spine-like setae on the hind first tarsomere, is described along with four new species from Australia and South America. A number of additional undescribed species remain, primarily from Australia, and these will be the focus of a future study that will examine the phylogeny of the genus and provide a key to species. This new genus can be identified using the keys to the ocydromiine genera (as undescribed genus A) and major empidoid groupings in Sinclair \& Cumming (2000).

In addition to validating the name Leptopezella, which unintentionally appeared as a nomen nudum in Sinclair \& Cumming (2006) (see below), several other corrections found in that paper are reported in the Appendix.

\section{Material and methods}

This study is based on material borrowed from or deposited in the following institutions: Australian Museum, Sydney, Australia (AMS); Canadian National Collection of Insects, Ottawa, Canada (CNC); United States National Museum of Natural History, Washington, DC, USA (USNM); Western Australian Museum, Perth, Australia (WAM); Zoologisches Forschungsmuseum Alexander Koenig, Bonn, Germany (ZFMK).

All dissections were made in glycerine and tissues cleared using hot $85 \%$ lactic acid. Terms used for adult structures primarily follow those of McAlpine (1981), except for the antenna and the wing venation where the terms of Stuckenberg (1999) and Saigusa (2006) are used, respectively. Homologies of the male terminalia 
follow those of Sinclair \& Cumming (2000, 2006). The following abbreviations are used: dc-dorsocentral bristles/setulae, npl—notopleural bristles, pal—postalar bristle, pprn—postpronotal bristle, sctl—scutellar bristles. Labels are listed from the top downward, with data from each label enclosed in quotation marks. Holotype labels are cited in full, in original spelling, punctuation and date, and lines are delimited by a slash mark (/).

\section{Leptopezella Sinclair \& Cumming, gen. nov.}

Leptopezella Sinclair \& Cumming 2006: 78, nomen nudum.

\section{Type species: Leptopezella spinosa, sp. nov.}

Diagnosis: This genus is easily separated from all other ocydromiine genera by the absence of crossvein $\mathrm{dm}$-cu and cell $\mathrm{dm}, \mathrm{M}$ vein evanescent, wing very slender with anal lobe not developed, and hind first tarsomere with spine-like ventral setae.

Description. Wing length $2.2-2.7 \mathrm{~mm}$.

Male (Fig. 1). Head dark, with extensive tomentum. Eye bare, dichoptic above, closely approximated immediately below antenna to just above mouthparts; anterior facets between antennae and mouthparts enlarged. Frons slightly divergent to nearly parallel-sided. Gena not extended below eye; postgena with sparse fine setae. One pair of ocellar bristles, directed forward. One pair of postocellar, 1 pair of vertical and 1-2 pairs of upper occipital setae. Antennae (Fig. 4) inserted above middle of head; scape slightly shorter than pedicel in length, scape devoid of setulae; pedicel cylindrical, with circlet of short preapical setulae; postpedicel elongate-ovate. Stylus arista-like, arising apicodorsally, longer than basal three segments; clothed in fine pubescence; apex with long, slender bristle-like mechanoreceptor (= segment 10 or apical style). Mouthparts (Fig. 5) small, not stout; length of proboscis less than one-quarter height of head; palpus short-ovate, flattened and slightly pointed apically; pale, two-thirds length of exposed proboscis with several prominent setae; labrum not recurved; hypopharynx arched gently on apical fourth; labellum weakly sclerotized, clothed in two rows of setulae; more than 10 pseudotracheae present; prementum thickly sclerotized laterally, membranous medially.

Thorax polished or finely clothed in tomentum; light to dark brown in colour, hunch-backed, postpronotal lobe and postalar callus well developed; prosternum separate from proepisternum; antepronotum well-developed. Thoracic macrotrichia mostly slender and short; acrostichal setulae uni- to biserial extending beyond transverse suture; dc uniserial; npl, pal and apical sctl long and strong. Meso- and metapleuron generally clothed in tomentum.

Wing (Fig. 2) hyaline, anal lobe not developed; short, only slightly longer than body; microtrichia uniform, clothed throughout; costal setae short; basal costal seta reduced; costa fading beyond $\mathrm{R}_{4+5}$; $\mathrm{Sc}$ evanescent, extending to beyond branching of $\mathrm{R}_{2+3}$ and $\mathrm{R}_{4+5}$; stigma very slender at apex of cell $\mathrm{r}_{1}$; Rs short, arising near apical third of cell $\mathrm{bm}$; cell $\mathrm{dm}$ absent; $\mathrm{M}$ vein unbranched, very weak, wavy and evanescent; cell bm pointed apically; $\mathrm{M}_{4}\left(\mathrm{CuA}_{1}\right)$ arched to wing margin; cell cua (cell cup or anal cell) two-thirds length of cell $\mathrm{bm} ; \mathrm{CuA}$ straight, strongly directed obliquely to base of wing; $\mathrm{CuP}+\mathrm{CuA}\left(\mathrm{A}_{1}\right)$ vein reduced, nearly equal in length of cell cua, not reaching wing margin (Fig. 2). Halter pale with whitish knob.

Legs pale proximally, darker distally, especially hindleg. Fore and midlegs much shorter and more slender than hindleg. Fore tibial gland present, occasionally expanded in male. Fore tibial anteroapical comb small. Hind femur slightly expanded apically; hind tibia clavate, strongly expanded, with large posteroapical comb. Hind tarsomeres expanded compared to other legs; tarsomere 1 at least half width of apex of hind tibia, bearing 1-2 rows of often black spine-like ventral setae (Fig. 3). 
Abdomen. Tergites generally well sclerotized, often darkly polished; sternites less sclerotized, generally paler. Sclerites of segment 8 not fused, tergite 8 approximately one-half to three-quarters length of tergite 7 . Hypopygium asymmetrical, rotated approximately $45^{\circ}$ to right. Hypandrium short and quadrate to elongate and produced apically; dorsal bridge straight. Epandrium deeply cleft, asymmetrical; left epandrial lamella usually with large spine-like seta at apex (many Australian species); surstyli asymmetrical, fully articulated. Bacilliform sclerites long and generally slender, bearing several setae. Cercus unmodified, short, slender and thinly sclerotized. Hypoproct often produced distally into asymmetrical hook-shaped process. Phallic shaft long, gradually arched, cylindrical, bearing long, spiralling, spinous, membranous distiphallus; ejaculatory apodeme rod-shaped, fused to base of phallus.

Female. Similar to male including head and legs except as follows: abdominal tergites 1 and 2 not fused; segments 1-7 broad, segments 2-6 nearly two times wider than long, width and length of segment 7 subequal; terminal segments partially retracted into $7^{\text {th }}$ (in dried specimens). Segment 8 four times longer than wide; tergite 8 longitudinally divided medially into 2 long slender sclerites, more weakly sclerotized distally; sternite 8 undivided medially; tergite 10 divided medially, widely separated and half length of sternite 10 . Cercus long and very slender, slightly less than half length of tergite 8 ; well sclerotized, bearing long scattered setae (Fig. 6).

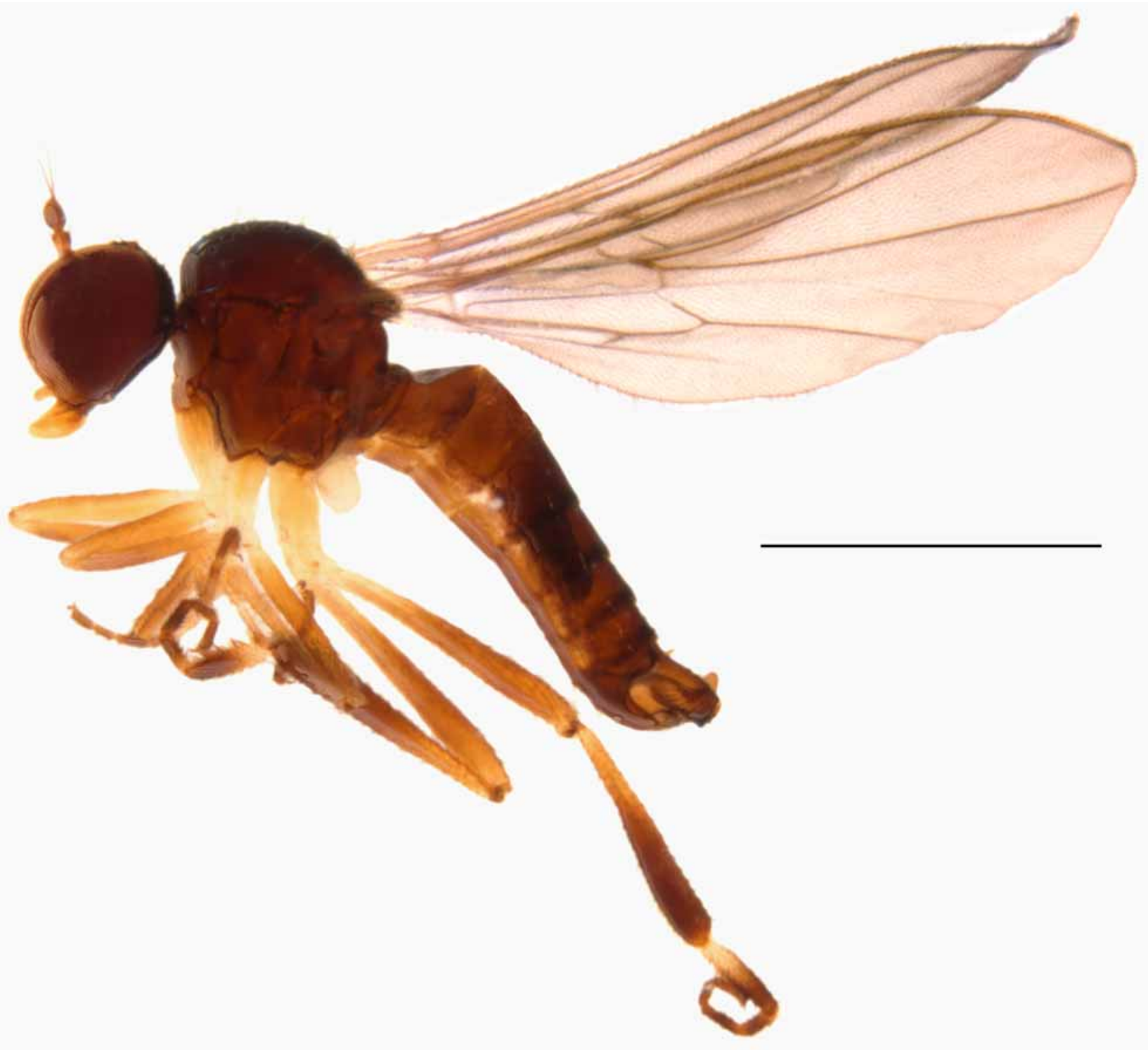

FIGURE 1. Leptopezella perata, sp. nov., habitus, lateral view. Scale bar $=1 \mathrm{~mm}$. 
Distribution and habitat. This genus is confined to South America (Bolivia, Argentina) and eastern and western Australia and apparently prefers moist or damp forest undergrowth. Specimens in Australia were swept from the under-story in wet sclerophyll and gallery rainforests in the Blue Mountains, temperate rainforests in Tasmania, the Otway Ranges (Victoria) and Border Ranges (Brindle Creek, New South Wales), and wet sclerophyll forests in Western Australia (Nornalup). In Bolivia, numerous specimens were swept from primary cloud forest at nearly $2000 \mathrm{~m}$.
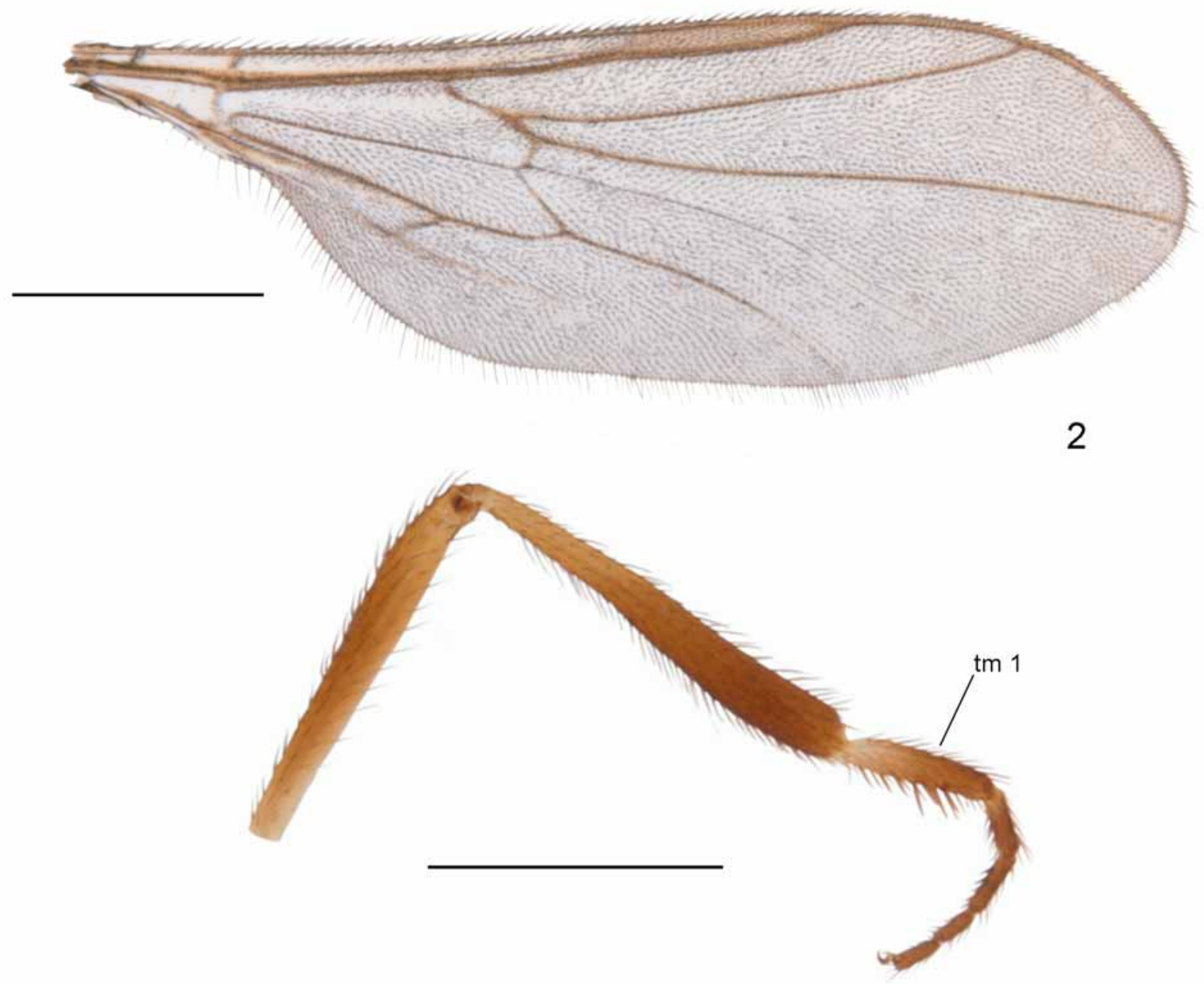

FIGURES 2-3. Leptopezella perata, sp. nov. 2. Wing. 3. Hind leg. Abbreviation: tm $1-$ first tarsomere. Scale bar $=0.5$ mm.

\section{Leptopezella anatolica, sp. nov.}

(Figs. 7-8)

Holotype male labelled: "AUST:NSW: Border/ Ranges NP, 1000m/ 25.i.1995; rainfor./ ex. Brindle Ck./ B.J. Sinclair"; "HOLOTYPE/ Leptopezella/ anatolica/ Sinclair \& Cumming” [red label]" (AMS).

Paratypes: Australia: New South Wales: Blue Mountains National Park, Blackheath, Govett's Leap, seeps below lookout, 1.xii.1993, B.J. Sinclair (1 ox, CNC); Blue Mountains National Park, Grand Canyon, rainforest stream, 25.xii.1993, B.J. Sinclair (1 ox, CNC); Brown Mountain, 50 kmW Bega, 1100 m, 28.i.1984, L. Masner (1 $\left.\sigma^{x}, \mathrm{CNC}\right)$. 
Recognition. This species is distinguished by the following features: frons and ocellar triangle with patches of tomentum, occiput completely clothed in tomentum, hypandrium cup-like, pair of rods dorsal to ejaculatory apodeme, left surstylus with broad base and right surstylus with long apical seta.

Description. Wing length $2.2 \mathrm{~mm}$.

Male. Scape and pedicel yellow, postpedicel dark from various angles. Frons and ocellar triangle faintly shiny, with patches of tomentum. Occiput clothed in grey tomentum; 3 long postocular bristles longer than ocellar bristles. Mouthparts yellow, including palpus.

Scutum dark and shiny; apex of postpronotal lobe yellow; lower notopleuron, postalar ridge and scutellum with grey tomentum. Acrostichals biserial, subequal in length with dc, extending length of scutum; 1 pprn with several long setulae; $1 \mathrm{npl}$ with many setulae; 1 long pal; dc uniserial; 2 pairs sctl, apical pair stouter and five times longer than lateral.

Fore and midlegs yellow, except tarsomere 5 darker. Fore tibia expanded about gland; setae surrounding gland pale. Hind femur as pale as anterior legs basally, darker on middle third, paler apically. Hind tibia pale basally; distal two-thirds very dark, nearly black. Hind tarsomeres dark; tarsomere 1 with 3-4 pairs of spinelike ventral setae, shorter than width of tarsomere; tarsomeres 2-3 with several stout, dark ventral setae.

Abdomen clothed in thin tomentum. Hypandrium cup-like (Fig. 7), long and prolonged distally, apex straight. Left epandrial lamella with sharp spine-like projection at base of apical spine-like seta; spine-like seta slightly shorter than left surstylus (Fig. 8). Left surstylus subtriangular with broad base; right surstylus finger-like, nearly parallel-sided, longer than left surstylus, with long apical seta. Hypoproct with short median projection. Pair of sclerotized rods dorsal to ejaculatory apodeme. Distiphallus with apical third spinose.

Female. Unknown.

Distribution. This species is known from moist forest habitats at about $1000 \mathrm{~m}$ in eastern New South Wales, from the southern coastal ranges, the Blue Mountains and the McPherson Range near the Queensland border.

Etymology. The specific name is derived from the Greek anatolikos (eastern), in reference to the eastern Australian distribution of this species.

\section{Leptopezella masneri, sp. nov.}

(Figs. 9-10)

Holotype male labelled: "BOLIVIA: LaPaz/ Chulumani, Apa-Apa/ 16²2'S.67³0'W/ 1-4.V.1997 1800m/ L.Masner s.s. B-09”; "HOLOTYPE/ Leptopezella/ masneri/ Sinclair \& Cumming” [red label]” (CNC).

Paratypes: Same data as holotype $\left(4 \circ^{x}, 17\right.$ 우, CNC).

Recognition. This species is distinguished by the following features: head, thorax and abdomen mostly shiny, male genitalia small, not expanded laterally beyond abdomen, left surstylus long and strongly arched, and hypoproct with long hook-like projection, arching to left side.

Description. Wing length $2.3-2.5 \mathrm{~mm}$.

Male. Scape and pedicel paler than postpedicel, postpedicel dark. Frons and ocellar triangle shiny. Occiput mostly shiny, thinly clothed in grey tomentum near middle; postocular bristles shorter than ocellar bristles. Mouthparts mostly dark, including palpus, except labellum yellowish from several oblique views.

Scutum dark and shiny; apex of postpronotal lobe yellow laterally; lower notopleuron, postalar ridge and proximal half of scutellum with thin grey tomentum. Acrostichals biserial, subequal in length with dc, extending half length of scutum; 1 pprn with several short setulae; 1 npl with many setulae; 1 long pal; dc uniserial; 2 pairs sctl, apical pair approximately three times longer than lateral. 


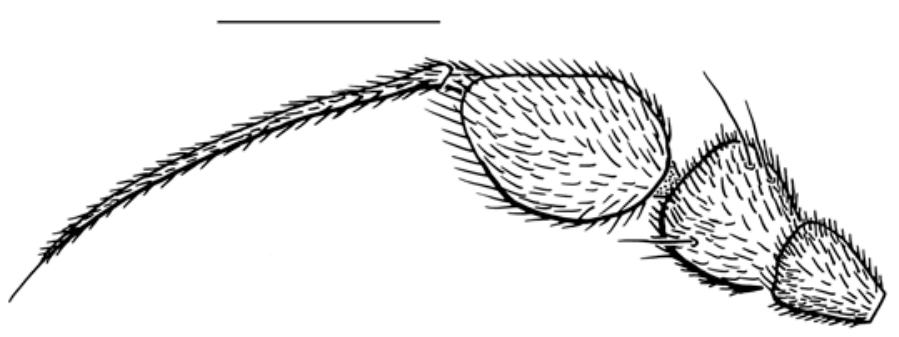

4
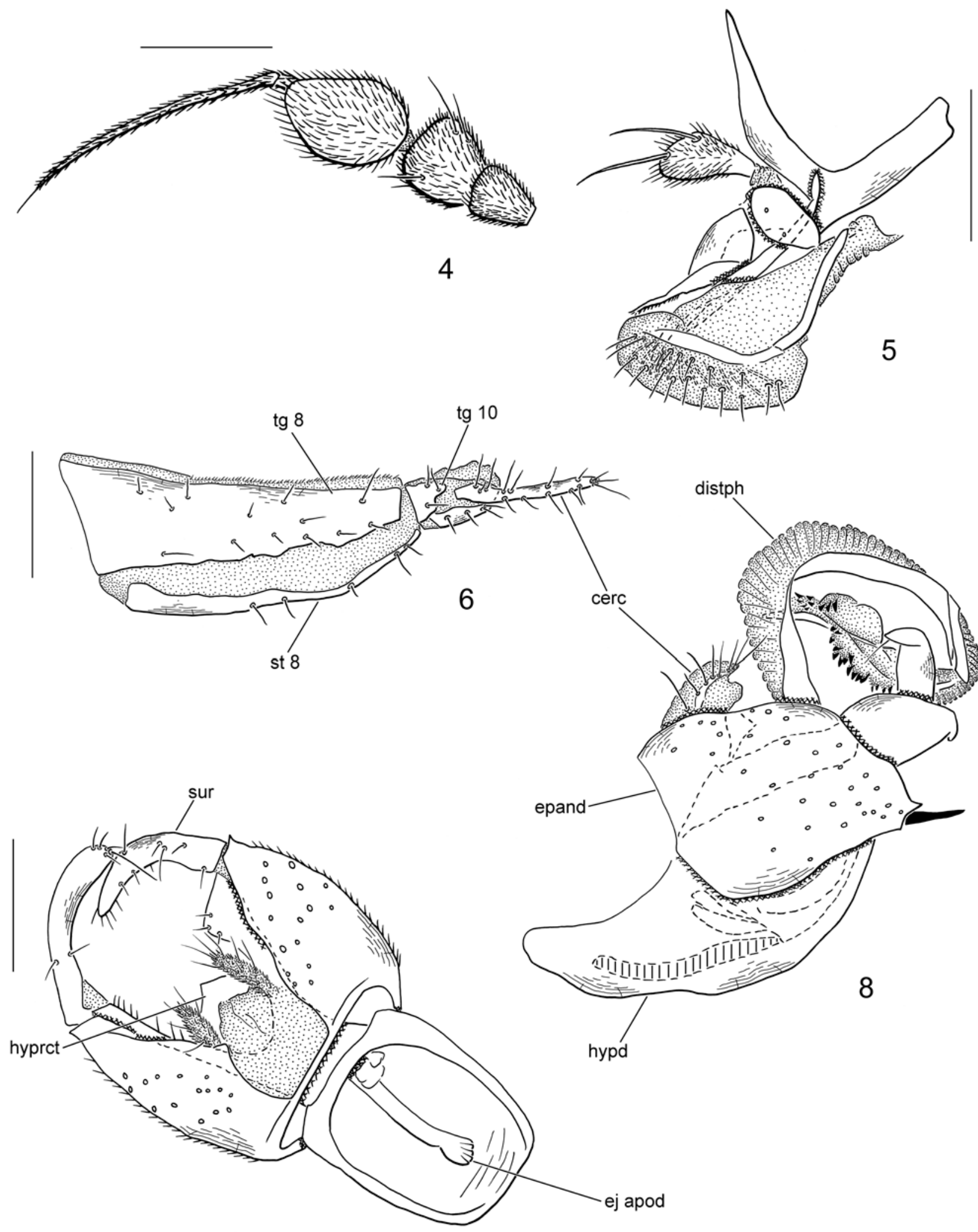

7

FIGURES 4-8. Antenna, mouthparts, female and male terminalia. 4. Leptopezella perata, sp. nov., antenna, lateral view. 5. L. perata, sp. nov., mouthparts, lateral view. 6. L. perata, sp. nov., female terminalia, lateral view. 7. L. anatolica, sp. nov., male terminalia, dorsal view with phallus removed. 8. L. anatolica, sp. nov., male terminalia, left lateral view. Abbreviations: cerc-cercus; distph-distiphallus; ej apod-ejaculatory apodeme; epand-epandrium; hypd-hypandrium; hyprct-hypoproct; sur-surstylus; st-sternite; tg-tergite. Scale bar = $0.1 \mathrm{~mm}$. 
Fore and midlegs paler than hindleg, gradually darker on distal tarsomeres. Fore tibia expanded about gland; dark setae surrounding gland. Hindleg gradually becoming darker distally, apex of tibia concolorous with tarsomeres. Hind tarsomeres dark; tarsomere 1 with spine-like ventral setae not in distinct pairs, 4-5 setae more stout than surrounding broad setae, shorter than width of tarsomere and not distinctly observed in lateral view; tarsomeres 2-3 with several stout, dark ventral setae.

Abdomen mostly shiny, lacking distinctive tomentum. Terminalia very small, half the size of Australian species. Hypandrium short and truncate distally, apex straight. Left epandrial lamella lacking spine-like projection and apical spine-like seta (Fig. 10). Left surstylus long and slender, longer than length of epandrium, strongly arched and gradually tapered towards rounded apex; right surstylus approximately two-thirds length of left, strongly arched on apical third (Fig. 9). Hypoproct with long hook-like projection, arching to left side. Sclerotized rods dorsal to ejaculatory apodeme absent. Distiphallus bare, lacking spinose projections.

Female. Similar to male, except setulae surrounding tibial gland pale.

Distribution. This species is known from only from the type locality in western Bolivia. The type series was swept from a protected, highly diverse, primary cloud forest.

Etymology. Named after Dr. Lubomir Masner (CNC) who collected the entire type series of this species.

Remarks. This species differs greatly from all the Australian species in terms of the small size of the male terminalia and specific genitalic features (see Discussion).

\section{Leptopezella perata, sp. nov.}

(Figs. 1-6, 11-12)

Holotype male labelled: "AUSTRALIA: WA/ Nornalup/ Valley of the Giants/ 4.xii.1998/ B.J. Sinclair/ ex. wet sclero.for."; "HOLOTYPE/ Leptopezella/ perata/ Sinclair \& Cumming” [red label]" (WAM).

Paratypes: Australia: Western Australia: Pemberton, Gloucester NP, below Gloucester Tree, 2.xii.1998, Karri forest, B.J. Sinclair (1 $0^{x}$, CNC); Warren NP, Karri forest, 30.xii.1998, B.J. Sinclair $\left(1 o^{x}, 1\right.$ ㅇ, CNC); Same data as holotype $\left(7 \circ^{\star}, 11\right.$ ․, AMS, CNC, WAM).

Recognition. This species is distinguished by the following features: occiput completely clothed in tomentum, right surstylus flattened and broadest in middle, and hypandrium not elongate with apex evenly rounded.

Description. Wing length $2.2-2.5 \mathrm{~mm}$.

Male. Scape and pedicel brownish, postpedicel similar in colour to basal segments at some angles. Frons and ocellar triangle shiny. Occiput clothed in grey tomentum; 1-2 long postocular bristles longer than ocellar bristles. Mouthparts yellow, including palpus.

Scutum dark and mostly shiny, some very thin tomentum visible at certain angles; apex of postpronotal lobe yellow; lower notopleuron, postalar ridge and scutellum with grey tomentum. Acrostichals biserial, subequal in length with dc, extending nearly length of scutum; 1 pprn with several long setulae; $1 \mathrm{npl}$ with many setulae; 1 long pal; dc uniserial; 2 pairs sctl, apical pair stouter and approximately four times longer than lateral.

Fore and midlegs yellow, darker on tarsomeres 2-5. Fore tibia expanded about gland; setae surrounding gland pale. Hind femur as pale as anterior legs basally, darker on middle third, paler apically. Hind tibia pale basally; distal two-thirds darker. Hind tarsomeres dark, except tarsomere 1 pale basally; tarsomere 1 with 3-4 pairs of spine-like ventral setae, distal pair nearly as long as width of tarsomere; tarsomeres 2-3 with several stout, dark ventral setae.

Abdomen mostly shiny. Hypandrium not elongated, with rounded apex. Left epandrial lamella with sharp spine-like projection at base of apical spine-like seta; spine-like seta one-fifth length of left surstylus (Fig. 12). Left surstylus arched with broad base; right surstylus flattened, broadest at mid-length, tapered towards 
broadly rounded apex (Fig. 11). Hypoproct with rounded distal margin. Sclerotized rods dorsal to ejaculatory apodeme absent. Distiphallus with apical two-thirds spinose.

Female. Similar to male.

Distribution. This species is known only from the wet sclerophyll forests of southwestern Australia.
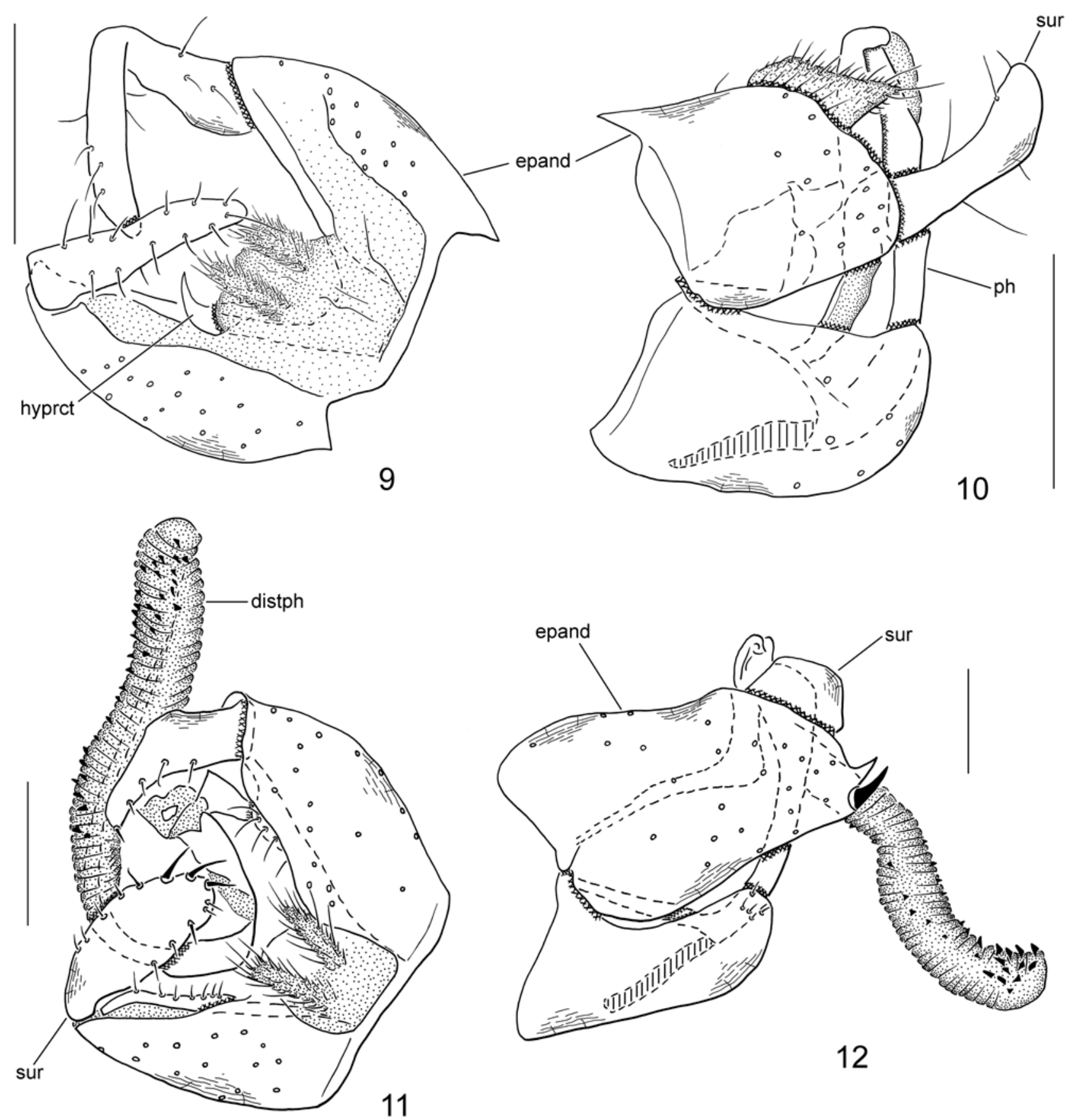

12

11

FIGURES 9-12. Male terminalia. 9. Leptopezella masneri, sp. nov., dorsal view with phallus removed. 10. L. masneri, sp. nov., left lateral view. 11. L. perata, sp. nov., dorsal view with phallus removed. 12. L. perata, sp. nov., left lateral view. Abbreviations: distph-distiphallus; epand-epandrium; hyprct-hypoproct; ph-phallus; sur-surstylus. Scale bar = $0.1 \mathrm{~mm}$. 
Etymology. The specific name is derived from the Greek peratos (west), in reference to the western Australian distribution of this species.

Remarks. At the Nornalup site, specimens were swept from along the trails of the wet sclerophyll forest, dominated by $60 \mathrm{~m}$ high red tingle (Eucalyptus jacksonii) trees. Specimens were also collected from karri (E. diversicolor) dominated forests.

\section{Leptopezella spinosa, sp. nov.}

(Figs. 13-15)

Holotype male labelled: “AUSTRALIA: TAS/ Launceston/ Cataract Gorge Res./ 14.xi.1999/ V. Zherikhin”; "HOLOTYPE/ Leptopezella/ spinosa/ Sinclair \& Cumming" [red label]" (AMS).

Paratypes: Australia: ACT: Canberra, Black Mountain, CSIRO, yellow pan trap, $35^{\circ} 16^{\prime} \mathrm{S} 149^{\circ} 06^{\prime} \mathrm{E}$, 25.x.-1.xi.1998, G. Gibson (2 ${ }^{\star}$, CNC). Tasmania: Same data as holotype, 9-10, 12-13, 23-24.xi.1999, V. Zherikhin (2 $\circ^{x}, 1$ ㅇ, AMS, ZFMK); Cradle Mountain, $860 \mathrm{~m}$, alpine forest, yellow pan traps, 20-22.ii.1993, B.J. Sinclair (1 ox, 1 ㅇ, CNC); Fern Tree, near Hobart, 27.iii.1980, G.F. Hevel \& J.A. Fortin (1 $\circ^{x}, 1$ 오, USNM); 16 kmNW Ouse, 28.iii.1980, G.F. Hevel \& J.A. Fortin (1 $\star^{x}$, USNM). Victoria: Otway Ranges, Melba Gully State Park, temperate rainforest, 4.xii.1994, B.J. Sinclair (1 $0^{x}$, CNC).

Recognition. This species is distinguished by the following features: upper portion of occiput shiny and lacking tomentum, spine-like setae on hind first tarsomere robust and long, hypandrium with hook-like projection on left corner, left epandrial lamella near base of left surstylus with spine-like seta, and hypoproct with hook-like left subapical projection.

Description. Wing length $2.5-2.6 \mathrm{~mm}$.

Male. Scape and pedicel yellowish on inner margin, postpedicel dark. Frons and ocellar triangle shiny, lacking tomentum. Occiput shiny on upper portion to level of setae, remaining clothed in grey tomentum; 2 long postocular bristles subequal to ocellar bristles. Mouthparts yellow, including palpus.

Scutum dark and shiny; apex of postpronotal lobe yellow; lower notopleuron, postalar ridge and scutellum with grey tomentum. Acrostichals biserial, subequal in length with dc, extending nearly length of scutum; 1 pprn with several long setulae; $1 \mathrm{npl}$ with many setulae; 1 long pal; dc uniserial; 2 pairs sctl, apical pair stouter and approximately three times longer than lateral.

Fore and midlegs yellowish, darker on tarsomeres 2-5. Coxae of all 3 legs distinctly paler compared to dark thorax. Fore tibia not expanded about gland; setae surrounding gland pale. Hind femur as pale as anterior legs basally, darker on middle third, paler apically. Hind tibia pale basally; distal two-thirds darker. Hind tarsomeres dark, except tarsomere 1 pale basally; tarsomere 1 with 3 pairs of spine-like ventral setae, distal 2 pairs longer than width of tarsomere; tarsomeres 2-3 with several stout, dark ventral setae.

Abdomen shiny. Hypandrium elongate, slightly twisted with asymmetrical apex; left corner of apex with long hooked projection; right side with rounded, V-shaped extension (Fig. 15). Left epandrial lamella with corner prolonged into rounded V-shaped prolongation beyond base of apical spine-like seta; apical spine-like seta one-half length of left surstylus; left epandrial lamella with additional spine-like seta near base of left surstylus (Fig. 13). Left surstylus strongly bent near mid-length with elbow-like expansion; apex truncate to slightly bifid. Right surstylus flattened, broadest at base, gradually arched and tapered towards rounded apex. Hypoproct stout, mostly truncate apically with hook-like subapical projection from left side. Sclerotized rods dorsal to ejaculatory apodeme absent. Distiphallus spinose for nearly entire length (Fig. 14).

Female. Similar to male.

Distribution. This species is known from forested regions of Tasmania and the southeastern mainland of Australia.

Etymology. This species is named in reference to the two spine-like setae on the left epandrial lamella and the robust spine-like setae on the hind first tarsomere. 

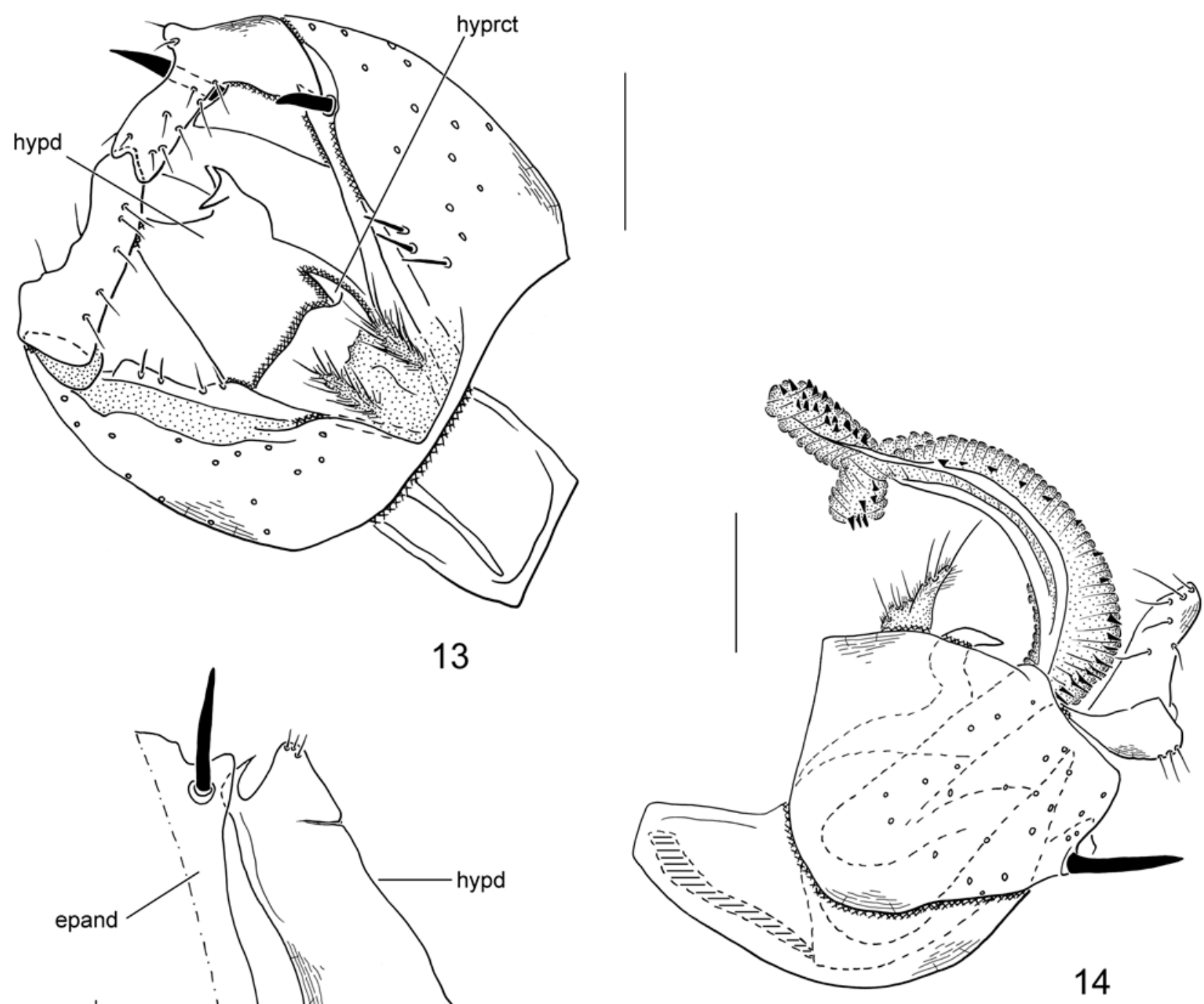

FIGURES 13-15. Male terminalia of Leptopezella spinosa, sp. nov., 13. Dorsal view with phallus removed. 14. Left lateral view. 15. Ventral view of hypandrium and left epandrial lamella. Abbreviations: epand-epandrium; hypd-hypandrium; hyprct-hypoproct. Scale bar $=0.1 \mathrm{~mm}$.

\section{Discussion}

All three described Australian species of Leptopezella are characterized by a distinct spine-like seta at the apex of the left epandrial lamella. This spine-like seta is also commonly associated with the development of a sharply pointed projection on the corner of the left epandrial lamella in certain species. However, an additional undescribed Australian species lacks this seta and corner projection. Interestingly, Leptopezella masneri from Bolivia lacks both these male genitalic features. Further study of other characters and additional undescribed species is required to determine if these features define a group of species within Australia. 
The generic relationships among the Ocydromiinae (sensu Sinclair \& Cumming 2006) were briefly discussed by Sinclair \& Cumming (2000), but no further information is available. Leptopezella is externally similar to Oropezella Collin on the basis of slender wings and long slender female cerci. A study of the generic relationships of the Ocydromiinae is needed and such an analysis should also address the generic limits of Hoplopeza Bezzi and Scelolabes Philippi, as well as the status of Stylocydromia Saigusa.

\section{Acknowledgments}

The following are thanked for their assistance: F.C. Thompson (USNM) helpfully informed us of several nomenclatural omissions found in our 2006 publication, which we have corrected in this study. N.E. Woodley generously arranged the loan of specimens from the USNM. The Department of Conservation and Land Management (Australia: WA) granted a licence (No. SF002664) for the collection of specimens to BJS. S.E. Brooks (CNC) and D.J. Bickel (AMS) kindly reviewed earlier versions of this paper.

\section{References}

McAlpine, J.F. (1981) Morphology and terminology - Adults. [Chapter] 2. In: McAlpine, J.F., Peterson, B.V., Shewell, G.E., Teskey, H.J., Vockeroth, J.R. \& Wood, D.M. (Coords.), Manual of Nearctic Diptera, Volume 1. Agriculture Canada Monograph, 27, 9-63.

Papp, L. \& Földvári, M. (2001) A new genus and three new species of Hybotidae with new records of the Hungarian Empidoidea (Diptera). Acta Zoologica Academiae Scientarum Hungaricae, 47, 349-361.

Saigusa, T. (2006) Homology of wing venation of Diptera. Unpublished handout distributed at the $6^{\text {th }}$ International Congress of Dipterology, Fukuoka, Japan, 26 pp.

Sinclair, B.J. \& Cumming, J.M. (2000) Revision of the genus Apterodromia (Diptera: Empidoidea), with a redefinition of the tribe Ocydromiini. Records of the Australian Museum, 52, 161-186.

Sinclair, B.J. \& Cumming, J.M. (2006) The morphology, higher-level phylogeny and classification of the Empidoidea (Diptera). Zootaxa, 1180, 1-172.

Stuckenberg, B.R. (1999) Antennal evolution in the Brachycera (Diptera), with a reassessment of terminology relating to the flagellum. Studia Dipterologica, 6, 33-48.

\section{Appendix. Corrections to Sinclair \& Cumming (2006)}

p. 12-under Trichopezinae, Apalocnemis was accidentally misspelled

p. 79-within the diagnosis of Drapetini, loss of $\mathrm{CuA}_{2}$ was inadvertently referred to as $\mathrm{CuA}_{1}$

p. 80-genera Pseudheleodromia Wagner and Cerathybos Bezzi were both accidentally misspelled

p. 80-Hyperperacera Collin was not listed in the Heterophlebus group of Trichopezinae even though it is mostly likely congeneric with Heterophlebus Philippi

p. 83-couplet 3 of Key to Families should read anteroventral gland rather than posteroventral gland

p. 160-label on Figure 329 indicated as lft sur should read lft cerc 
